\title{
PReS-FINAL-2311: Rituximab in paediatric ANCA-associated vasculitis
}

\author{
G Mestrallet ${ }^{1}$, A Faye ${ }^{2}$, P Quartier ${ }^{3}$, B Ranchin ${ }^{4}$, P Cochat $^{4}$, A Belot ${ }^{4 *}$, SOFREMIP \\ From 20th Pediatric Rheumatology European Society (PReS) Congress \\ Ljubljana, Slovenia. 25-29 September 2013
}

\section{Introduction}

Rituximab is an anti-CD20 monoclonal antibody that has proven to be effective in the treatment of ANCAassociated vasculitis (AAV) in adults. Standard treatments rely on corticosteroids and cyclophosphamide. Only isolated case reports of pediatric AAV treated by rituximab have been reported so far.

\section{Objectives}

Our objective was to collect clinical data and outcomes of children with AAV treated with rituximab in a multicenter retrospective study.

\section{Methods}

We conducted a retrospective study within the French paediatric rheumatology society (SOFREMIP) in 20112012.

\section{Results}

We identified 6 children with AAV treated with rituximab (microscopic polyangeitis, $\mathrm{n}=2$, granulomatosis with polyangeitis, $\mathrm{n}=2$, unspecified vasculitis, $\mathrm{n}=2$ ). The age at onset ranged from 4 to 16 yrs. Treatment with rituximab consisted in 4 infusions of $375 \mathrm{mg} / \mathrm{m}^{2}$; one patient received only 3 infusions. Mean duration of follow-up was $2.65 \mathrm{yrs}$. All patients achieved clinical remission after 12 months. One patient presented several relapses associated with $B$ cell increase and was dependent on rituximab infusions. No severe adverse event had been reported.

\section{Conclusion}

From this multicenter retrospective series, short-term safety and efficicacy of rituximab in pediatric AAV is

${ }^{4}$ Pediatric Nephrology, Rheumatology \& Dermatology Department, HOPITAL FEMME MERE ENFANT, HOSPICES CIVILS DE LYON, Lyon, France

Full list of author information is available at the end of the article promising so that B cell depleting agents may represent an alternative to conventional treatment with cyclophosphamide but larger prospective studies are mandatory.

\section{Disclosure of interest}

None declared.

\section{Authors' details}

${ }^{1}$ Pediatrics, CH Villefranche Hospital, Villefranche sur Saone, France. ${ }^{2}$ Pediatric Rheumatology \& Infectious Diseases Department, Hopital Robert Debré, Assistance Publique Hopitaux de Paris, Paris, France. ${ }^{3}$ Pediatric Rheumatology department, Hopital Necker, Assistance Publique Hopitaux de Paris, Paris, France. ${ }^{4}$ Pediatric Nephrology, Rheumatology \& Dermatology Department, HOPITAL FEMME MERE ENFANT, HOSPICES CIVILS DE LYON, Lyon, France.

Published: 5 December 2013

\section{doi:10.1186/1546-0096-11-S2-P301}

Cite this article as: Mestrallet et al:: PReS-FINAL-2311: Rituximab in paediatric ANCA-associated vasculitis. Pediatric Rheumatology 201311 (Suppl 2):P301.
Submit your next manuscript to BioMed Central and take full advantage of:

- Convenient online submission

- Thorough peer review

- No space constraints or color figure charges

- Immediate publication on acceptance

- Inclusion in PubMed, CAS, Scopus and Google Scholar

- Research which is freely available for redistribution
() Biomed Central
C Biomed Central

(c) 2013 Mestrallet et al.; licensee BioMed Central Ltd. This is an Open Access article distributed under the terms of the Creative Commons Attribution License (http://creativecommons.org/licenses/by/2.0), which permits unrestricted use, distribution, and reproduction in any medium, provided the original work is properly cited. The Creative Commons Public Domain Dedication waiver (http://creativecommons.org/publicdomain/zero/1.0/) applies to the data made available in this article, unless otherwise stated. 